\title{
Cold-season soil respiration in response to grazing and warming in High-Arctic Svalbard
}

\author{
Ditte Strebel, ${ }^{1,2}$ Bo Elberling, ${ }^{1,2}$ Elke Morgner, ${ }^{2,3}$ Heike E. Knicker ${ }^{4}$ \& Elisabeth J. Cooper ${ }^{3}$ \\ 1 Department of Geography and Geology, University of Copenhagen, Øster Voldgade 10, DK-1350 Copenhagen K., Denmark \\ 2 Department of Arctic Biology, University Centre in Svalbard, PO Box 156, NO-9171 Longyearbyen, Norway \\ 3 Department of Arctic and Marine Biology, University of Tromsø, NO 9037 Tromsø, Norway \\ 4 Department of Geoecology and Biogeochemistry, Institute for Natural Resources and Agrobiology, Avda. Reina Mercedes 10 , ES-41012 Sevilla, Spain
}

\section{Keywords}

Goose grazing; soil respiration; SOC turnover;

Spitsbergen; tundra vegetation; warming.

\section{Correspondence}

Bo Elberling, Department of Geography and Geology, University of Copenhagen, Øster Voldgade 10, DK-1350 Copenhagen K., Denmark. E-mail: be@geo.ku.dk

doi:10.1111/j.1751-8369.2010.00154.x

\begin{abstract}
The influence of goose grazing intensity and open-topped chambers (OTCs) on near-surface quantities and qualities of soil organic carbon (SOC) was evaluated in wet and mesic ecosystems in Svalbard. This study followed up a field experiment carried out in 2003-05 (part of the project Fragility of Arctic Goose Habitat: Impacts of Land Use, Conservation and Elevated Temperatures). New measurements of soil $\mathrm{CO}_{2}$ effluxes, temperatures and water contents were regularly made from July to November 2007. SOC stocks were quantified, and the reactivity and composition measured by basal soil respiration (BSR) and solid-state ${ }^{13} \mathrm{C}$ nuclear magnetic resonance (NMR) spectroscopy. Results reveal variations in soil carbon cycling, with significant seasonal trends controlled by temperature, water content and snow. Experimental warming (OTCs) increased near-surface temperatures in the growing season, resulting in significantly higher $\mathrm{CO}_{2}$ effluxes. Different grazing intensities had no significant effects on observed soil respiration, but BSR rates at the mesic site (13$23 \mu \mathrm{g} \mathrm{CO} \mathrm{g}_{2}$ soil- $\mathrm{C}^{-1} \mathrm{~h}^{-1}$ ) were highest with moderate grazing and lowest in the absence of grazing. A limited effect of grazing on microbial respiration is consistent with a lack of significant differences in SOC quantity and quality. NMR data show that the composition of A-horizon SOC is dominated by $\mathrm{O}-\mathrm{N}$-alkyl $\mathrm{C}$ and alkyl $\mathrm{C}$ groups, and less by carboxyl $\mathrm{C}$ and aromatic $\mathrm{C}$ groups: but again no marked variation in response to grazing was evident. It can be concluded that two years after a goose grazing experiment, SOC cycling was less than the natural variation within contrasting vegetation types.
\end{abstract}

Tundra ecosystems play a critical role in global carbon cycling: soil organic carbon (SOC) accumulates over many years because primary production rates typically exceed the low decomposition rates. The stock of SOC in tundra ecosystems has been estimated to be about $400 \mathrm{Pg} \mathrm{C}$, or more than $16 \%$ of the world's soil carbon pool (Lal et al. 2000; Luo \& Zhou 2006). The SOC sink capacity is particularly sensitive to processes that either reduce primary production rates or increase decomposition rates (Sjögersten et al. 2008).

Herbivores can affect the functioning of ecosystems at a local scale, and geese are among the most abundant herbivores in the Arctic (Abraham et al. 2005). Goose grazing reduces the level of photosynthetically active above-ground biomass, and hence the potential rate of primary production. In addition, goose faeces change the composition of SOC input (Brady \& Weil 2004) and potentially increase decomposition rates. The impact of increased above-ground herbivore activity may therefore play a significant role in elemental cycling in these ecosystems (Jónsdóttir 2005), and may result in elevated SOC sink strength in future.

Geese are very specific grazers (Cooper et al. 2006; Küijper et al. 2006), and this, together with a reduction in regrowth following intense grazing (Cooper et al. 2006), may lead to changes in vegetation composition in the long term. Geese also remove below-ground biomass during grubbing, and the resulting holes in the soil may cause erosion of the soil organic layer (van der Wal et al. 2007). Thus, marked changes in herbivore activity can 
substantially affect plant biomass, species composition and physical soil properties, and thereby elemental cycling and nutrient availability in the soil. Understanding the responses of biota and soil systems to grazing and climate change is important for calculating the longterm carbon sink/source capacity of Arctic ecosystems (Sjögersten et al. 2008).

Along the coast of Hudson Bay, a dramatic increase in snow goose population has led to the suppression of primary productivity, nutrient loss and erosion of the soil organic horizon (Srivastava \& Jefferies 1996; Jefferies et al. 2006). In Svalbard, the populations of pink-footed geese (Anser brachyrhynchus) and barnacle geese (Branta leucopsis) have also increased greatly in the past 30 years because of their improved survival during their winter stay in western Europe (Fox et al. 2005), as well as reduced hunting pressure (Cooper et al. 2004). Concerns that vegetation in Svalbard could suffer from similar ecosystem degradation as that seen in Canada was the basis for the project Fragility of Arctic Goose Habitat: Impacts of Land Use, Conservation and Elevated Temperatures (FRAGILE), funded by the European Union. A field experiment was conducted from 2003 to 2005 to investigate the combined role of increased goose grazing intensity and climate warming on the tundra (Cooper et al. 2004). Grazing intensities of up to 3.4 times that normally observed in the field were created in the FRAGILE plots by the use of captive geese in enclosures. This was not enough to cause as much habitat degradation as that observed in the Hudson Bay Lowlands (Sjögersten et al. 2008), even though the ability for plant regrowth was reduced at experimentally high grazing intensities (Cooper et al. 2006). Ecosystem $\mathrm{CO}_{2}$ fluxes were estimated in FRAGILE plots by measuring net ecosystem exchange (NEE) of $\mathrm{CO}_{2}$, ecosystem respiration (Re) and gross ecosystem photosynthesis (GEP) during the growing season (Sjögersten et al. 2008). Both grazing and warming treatments showed immediate effects on the ecosystem $\mathrm{CO}_{2}$ fluxes at the start of the experiment in 2003, but the treatments had different effects on $\mathrm{CO}_{2}$ fluxes at the two sites. In particular, the wet site was highly responsive to herbivore-driven removal of plant biomass, which caused a significant reduction in GEP and a corresponding reduction in carbon sink strength. At the mesic site, elevated temperatures had a greater effect than grazing, and altered the carbon balance during the growing season from a source to a weak net sink of carbon (Sjögersten et al. 2008). The role of the soil system was not evaluated in detail at that time, despite the fact that the longer term impact on vegetation growth is likely to be partly controlled by potential changes in the soil, and that the sink capacity of the soil for carbon far exceeds that of the vegetation.
The direct effect of increasing soil temperatures on soil respiration is commonly described using simple temperature sensitivity equations (Fang \& Moncrieff 2001), whereas indirect effects include changes in the availability of substrate and liquid water as a function of soil temperatures (Davidson \& Janssens 2006). Arctic ecologists have long focused on soil processes occurring during the "growing season", although subsurface conditions during the cold season are more complex in terms of substrate availability, and the soil temperatures are higher than expected compared with above-ground temperatures. Particularly at the onset of the cold season, the active layer is at its maximum thickness, and the temperature remains at $0^{\circ} \mathrm{C}$ or slightly below for several months. In fact, research over the last decade has convincingly demonstrated that the period beyond the growing season constitutes an important component of annual carbon budgets (Fahnestock et al. 1998; Fahnestock et al. 1999). The accurate prediction of future soil carbon balance therefore relies on an improved understanding of direct climate controls as well as indirect environmental and biological controls of soil respiration year-round. So far it is unknown how near-surface SOC and nitrogen cycling are influenced by changes in herbivore activity, the importance of manure on the surface, and the duration of possible interacting effects at ambient and elevated temperatures.

Therefore, the aims of this study are to quantify longer term effects of the FRAGILE field experiment on the soil system, with a specific focus on the quantity and quality of below-ground carbon, and on rates of soil $\mathrm{CO}_{2}$ respiration. "Longer term" refers to measurable treatment effects two years after the last grazing treatment was applied, whereas warming treatments have been continued each summer since the start of the experiment in 2003. This study includes measurements from the growing season and also the transition to the cold and dark season in order to provide a more robust model for estimates of annual soil respiration. We hypothesized that soil carbon turnover responds to grazing as a result of the increased input of SOC to the soil system, and that this SOC would be more quickly decomposed by the soil microfauna, which in turn could lead to a decreased SOC sink strength. Finally, after the grazing experiment was terminated, we expected the effect on the soil system to decline after several growing seasons.

\section{Materials and methods}

\section{Study site}

The present study was carried out on the original FRAGILE experimental site in Adventdalen, Spitsbergen 
$\left(78^{\circ} 10^{\prime} \mathrm{N}, 16^{\circ} 06^{\prime} \mathrm{E}\right)$, a valley created by meltwater from the surrounding upland that hosts several glaciers, which has been dominated by fluvial and aeolian sedimentation since the last deglaciation. The climate is characterized by a mean annual air temperature of around $-4.2 \pm$ $2.1^{\circ} \mathrm{C}$ and an annual precipitation of $262 \pm 57 \mathrm{~mm}$ (1997-2007) (data available at http://www.eklima.no). Approximately $50 \%$ of the precipitation falls as snow (1995-2004, as measured at the meteorological station at Adventdalen; data available at http://www.unis.no). The study was located within the region of continuous permafrost, with an active layer depth of 1.0-1.3 m.

There is a clear distinction between several vegetation types with respect to species composition and vegetation cover, reflecting the hydrological regimes at the FRAGILE site. Two vegetation types were studied: the mesic site was well-drained, exposed and located on the outer part of an alluvial fan buried below aeolian sediment. The snow cover was thin or absent throughout winter. The sparse dwarf shrub/grass heath vegetation was dominated by Salix polaris, Alopecurus borealis, Luzula acuata ssp. confusa and Bistorta vivipara. A moss mat composed of Tomenthypnum nitens, Hylocomnium splendens and Sanionia uncinata covered most of the soil. The wet site was located along a meandering meltwater stream, generating wet minerotrophic conditions. The moss cover was almost $100 \%$ and was dominated by Calliergon richardsonii. The dominant vascular species were Dupontia fisherii and Equisetum arvense, with smaller numbers of Calamagrostis stricta and forbs, e.g., Bistorta vivipara and Cardamine nymanii. The maximum snow depth in this flat low-lying area was $1.5 \mathrm{~m}$. The two habitats are representative of areas visited by geese during pre-breeding or breeding seasons in Svalbard. Areas near the mesic site are used as foraging grounds by pink-footed geese during a brief period in spring, although the vegetation present is typically intensely grazed by barnacle geese during the breeding season in this and other areas. The lack of nearby lakes as a safe refuge from Arctic foxes (Vulpes lagopus) deters geese from using these areas during the breeding season. A residential population of reindeer (Rangifer tarandus) graze the surrounding areas. However, they were effectively excluded from the plots by boardwalks and fencing.

The FRAGILE plots used for the present study were established in 2003 with grazing (three levels) and warming (two levels) in a randomized block design, where $n=5$, and plot size $=2 \times 2 \mathrm{~m}$ (Cooper et al. 2006). The same design was used for the mesic and wet sites. Open top chambers (OTCs) were used to artificially increase the air temperature. At the mesic site, soil surface temperatures were raised by $1^{\circ} \mathrm{C}$, whereas no significant warming was detected at the wet site. Air temperature $10 \mathrm{~cm}$ above the ground surface was increased by ca. $5^{\circ} \mathrm{C}$ around midday at both sites (Sjögersten et al. 2008). The OTCs were put in place at the start of the growing season, and those on the mesic site were removed at the end of summer because of concerns about snow accumulation, whereas those on the wet site were kept in place. The warming treatment has continued each summer since 2003.

Grazing was carried out using pairs of captured wild barnacle geese in cages $(2 \times 2 \mathrm{~m})$ for 1 or $5 \mathrm{~h}$, and the resulting grazing pressure was in the range of that naturally found in the field or was considerably higher (Cooper et al. 2004; Küijper et al. unpubl. ms.). The grazing treatments were repeated twice during the growing seasons in 2003 and 2004 (first week of July and August), and once in 2005 (July). Geese behaved relatively normally despite being in a cage, and their peck rates, step rates and dropping rates were similar to those in the field (Küijper et al. unpubl. ms.). Droppings were left in place after removal of the geese.

Each block was ca. $15 \times 20 \mathrm{~m}$ in area, with a minimum distance between the blocks of about $10 \mathrm{~m}$. Each block contained six plots, one replicate of each grazing and temperature combination: ungrazed, at ambient temperature; low grazing, i.e., two geese grazing for $1 \mathrm{~h}$, at ambient temperature; high grazing, i.e., two geese grazing for $5 \mathrm{~h}$, at ambient temperature; ungrazed with OTC; low grazing with OTC; and high grazing with OTC.

\section{Soil respiration and $\mathrm{CO}_{2}$ effluxes in the field}

Ecosystem respiration (microbial, root and plant respiration) was measured by means of an infrared gas analyser (LI-COR 6400-09/6262 Soil $\mathrm{CO}_{2}$ Flux Chamber; LI-COR Biosciences, Lincoln, NE, USA). The $\mathrm{CO}_{2}$ analyser (nondispersive infrared analyser) was attached to a portable chamber, functioning as a dark and closed soil-flux chamber. According to the LI-COR, the observed flux is dominated by subsurface respiration, and is therefore assigned as soil respiration. The flux chamber was placed on top of open pre-installed (2 months) dark collars $(10 \mathrm{~cm}$ high and $10 \mathrm{~cm}$ in diameter). Subsequently, absolute values of both sample and reference mole fractions $\left(\mathrm{CO}_{2}\right.$ and $\left.\mathrm{H}_{2} \mathrm{O}\right)$ were measured continuously over 2-3 min. The $\mathrm{CO}_{2}$ efflux was calculated on the basis of a linear increase $\left(R^{2}>0.95\right)$ in chamber $\mathrm{CO}_{2}$ concentrations over time. During the winter, the LI-COR system was kept in an isolated and heated container to keep temperatures above freezing point. A similar set-up was used in other studies (Elberling et al. 2004), and provided accurate and consistent results (Healy et al. 1996). Measurements were made on one collar in each treatment combination in all five blocks, representing five replicates per treatment combination, at roughly a 
fortnightly basis from July to November 2007. During wintertime, snow was removed in order to reach the collars and was replaced after measurements.

The volumetric soil water content was monitored using a handheld soil moisture sensor (Theta Probe ML2x; Delta-T Devices Ltd, Cambridge, UK), which responds to changes in the apparent dielectrical constant. These changes are converted into a DC voltage, which is proportional to soil water content over a wide working range of specific soil types (Gaskin \& Miller 1996). Five replicate readings of the near-surface water content $(0-5 \mathrm{~cm})$ were made at the same time as the ecosystem $\mathrm{CO}_{2}$ efflux measurements (five readings for each of the LI-COR collars). Temperatures were recorded at 2 and $4 \mathrm{~cm}$ depth at two blocks in each vegetation type once every $2 \mathrm{~h}$ using Gemini Data Loggers (Tinytag, Chichester, West Sussex, UK).

Depth- and volume-specific soil samples were collected using a soil core ( $5 \mathrm{~cm}$ in diameter and $15 \mathrm{~cm}$ in length) at all replicate plots in both sites in August 2007. Samples were stored in the dark at about $7^{\circ} \mathrm{C}$ until analysed in the laboratory.

\section{Chemical analysis and basal soil respiration}

Soil pH was measured in situ in a soil-solution paste in both plots after a minimum of distilled water had been added (less than half the mass of the soil) to produce a paste. The distribution of grain sizes was obtained by sieving. Bulk density was determined on the basis of the weight of dried volume-specific soil cores. All other chemical soil analyses were made using only the soil fraction finer than $2 \mathrm{~mm}$. Total organic carbon (TOC) was measured after acidification, using $6 \mathrm{M} \mathrm{HCl}$ to remove inorganic carbon, and was subsequently analysed using the dry combustion method at $1250^{\circ} \mathrm{C}$ on an Eltra SC-500 analyser (Eltra, Neuss, Germany), with an accuracy of $\pm 0.2 \%$. Total nitrogen was analysed using dry combustion and infrared detection of $\mathrm{N}$ using a Leco FP-428 v2.03 apparatus (Leco, St. Joseph, MI, USA), with an accuracy of $\pm 0.05 \%$.

Basal soil respiration rates were measured in the laboratory using bulk samples from A horizons from all the mesic plots. Samples had been stored in polyethylene bags at $0-4^{\circ} \mathrm{C}$. Prior to measurement, soil samples were carefully split to remove roots and stones ( $>5 \mathrm{~mm}$ ). After an initial pre-incubation time of $48 \mathrm{~h}$ at $5.0 \pm 0.5^{\circ} \mathrm{C}$, weighed soil samples (equivalent to about $5 \mathrm{~g}$ of dry soil) were transferred to $12-\mathrm{ml}$ Venoject tubes, left for a preincubation period of $2 \mathrm{~h}$ and out-gassed with $\mathrm{CO}_{2}$-free air for $5 \mathrm{~min}$. Soil respiration was subsequently measured by monitoring the linear $\left(R^{2}>0.9\right)$ increase of headspace $\mathrm{CO}_{2}$ concentrations, measured three times over $5 \mathrm{~h}$ by gas chromatography, using a ML-GC8212 MicroLab (MicroLab, Bozeman, MT, USA) equipped with a Porapak Q column kept at $30^{\circ} \mathrm{C}$ and a thermal conductivity detector (Mikrolab Aarhus, Aarhus, Denmark), operated at $200^{\circ} \mathrm{C}$ and a flow rate of $25 \mathrm{ml} \mathrm{He} \mathrm{min}^{-1}$. All measurements were made at constant temperatures: $5.0 \pm 0.5^{\circ} \mathrm{C}$. Previous experiments show that $\mathrm{CO}_{2}$ diffusion into tubes was negligible, and that sample splitting had little influence on $\mathrm{CO}_{2}$ production rates (Elberling \& Brandt 2003).

Solid state ${ }^{13} \mathrm{C}$ nuclear magnetic resonance (NMR) spectroscopy was carried out on pulverized bulk soil obtained from the A horizon at all the mesic sites, as described by Knicker \& Ludemann (1995) and Knicker et al. (2005). Samples were prepared by crushing $15 \mathrm{~g}$ of material in a mortar, followed by treatment in an agate ball-mill for at least 30 min until a very fine-grain powder was obtained and finally treated with $10 \%$ hydrofluoric acid (HF). The solid-state ${ }^{13} \mathrm{C}$ NMR spectra were obtained on a Bruker DSx 200 (Bruker AXS Inc., Madison, WI, USA) operating at a ${ }^{13} \mathrm{C}$ resonance frequency of $50.3 \mathrm{MHz}$, using zirconium rotors of $7 \mathrm{~mm}$ outer diameter with KEL-Fcaps (3M, Minneapolis, MN, USA). The cross polarization magic-angle spinning (CPMAS) technique was applied during magic-angle spinning of the rotor at $6.8 \mathrm{kHz}$. A ramped ${ }^{1} \mathrm{H}$ pulse was used during contact time in order to circumvent spin modulation of Hartmann-Hahn conditions. A contact time of $1 \mathrm{~ms}$ and a $90^{\circ}{ }^{1} \mathrm{H}$ pulse width of $6.2 \mathrm{~ms}$ were used for all spectra. The ${ }^{13} \mathrm{C}$ chemical shifts are given with respect to tetramethylsilane $(=0 \mathrm{ppm})$, and were calibrated with the carboxyl carbon of glycine (176.04 ppm). The pulse delays were between 200 and $500 \mathrm{~ms}$ and 2700 and 35500 scans were accumulated for the samples.

\section{Calculations and statistical analysis}

The SOC content per soil layer was calculated by multiplying carbon concentrations by soil density and soil layer thickness. The soil carbon stock was estimated to a depth of $0.15 \mathrm{~m}$ by depth-integrating the SOC content in the soil layers. Statistical analyses were carried out using SPSS and EXCEL software for evaluating any significant $(P<0.05)$ variations between vegetation types and treatment (one-way ANOvA). Relationships between respiration rates, temperatures and soil characteristics were determined using linear regression, and were only reported when significant $(P<0.05)$.

\section{Results and discussion}

\section{Soil characteristics and element stocks}

The mesic site had an $\mathrm{O}$ horizon of $2 \mathrm{~cm}$ (ranging from 0.2 to $6 \mathrm{~cm}$ ), consisting of slightly decomposed organic 
matter and many live plant roots. Below that was a darkbrown A horizon with an average thickness of $2 \mathrm{~cm}$ $(1-5 \mathrm{~cm})$. B/C horizons below were fairly uniform, consisting of grey silt. Living plant roots were found to a depth of $45 \mathrm{~cm}$. Replicate profiles revealed great spatial variations in the depths of the water table $(45-60 \mathrm{~cm}$ below the surface) and the active layer thickness (50$80 \mathrm{~cm}$ ). At the wet site, the depth of the active layer was not determined because of a compact gravel layer about $15 \mathrm{~cm}$ below the surface. In similar wet Arctic tundra, active layer depths have been reported to reach 20-60 cm (Billings et al. 1977). The upper part of the soil cores consisted of an organic peat horizon (H horizon), with poorly decomposed organic matter of average thickness of $4 \mathrm{~cm}(1-7 \mathrm{~cm})$, which was water-saturated for most of the growing season. A grey-coloured A horizon below consisted of partly decomposed organic matter, and an increased level of mineral particles with depth. The average depth for the A horizon was $5 \mathrm{~cm}(3-9 \mathrm{~cm})$. A grey-blue $\mathrm{B} / \mathrm{C}$ horizon was found below the A horizon.

The soil texture was generally coarser at the mesic site compared with the wet site. At the mesic site, the soil fraction finer than $63 \mu \mathrm{m}$ was about $20 \%$ by mass in the A horizon, whereas at the wet site the fine fraction was above $25 \%$ (up to $40 \%$ ). The mean grain size was about $200 \mu \mathrm{m}$ for both A horizons. The soil bulk density (Fig. la) increased with depth from about 0.09 to $1.6 \mathrm{~g} \mathrm{~cm}^{-3}$ at the mesic site, and from about 0.04 to
$1.2 \mathrm{~g} \mathrm{~cm}^{-3}$ at the wet site. In the $\mathrm{O}$ horizon at the mesic site, soil bulk density ranged from 0.09 to $0.2 \mathrm{~g} \mathrm{~cm}^{-3}$; in the $\mathrm{H}$ horizon at the wet site, soil bulk density ranged from 0.04 to $0.06 \mathrm{~g} \mathrm{~cm}^{-3}$. Also, the A horizon at the mesic site generally had a higher bulk density at $0.2-0.3 \mathrm{~g} \mathrm{~cm}^{-3}$ compared with $0.08-0.3 \mathrm{~g} \mathrm{~cm}^{-3}$ at the wet site. In situ soil $\mathrm{pH}$ values ranged from 5.0 to 6.5 down the profiles, and assigned them to moderately acidic soils (Fig. 1).

The content of SOC and total nitrogen were highest in the topsoil, and decreased with depth (Fig. 1). At the mesic site, SOC was $27 \%$ in the O horizon, $15-25 \%$ in the A horizon, $3-8 \%$ in the shallower layer of $\mathrm{B} / \mathrm{C}$ horizons and below $3 \%$ in the deeper $\mathrm{B} / \mathrm{C}$ horizons. At the wet site, SOC was $28 \%$ in the $\mathrm{H}$ horizon, $6 \%$ in the $\mathrm{A}$ horizon, $3.5-5.5 \%$ in the shallower $\mathrm{B} / \mathrm{C}$ horizons and $2.5-3.0 \%$ in the deeper $\mathrm{B} / \mathrm{C}$ horizons. The nitrogen content was about $1 \%$ in the A horizon at the mesic site and O horizon at the wet site, and ranged at both sites between 0.07 and $0.60 \%$ in the horizons below. The $\mathrm{C} / \mathrm{N}$ ratio (Fig. 1) generally decreased with depth at both sites. The SOC and total nitrogen contents refer to the soil fraction with a particle size below $2 \mathrm{~mm}$; it was assumed that the SOC and total nitrogen contents of soil fractions larger than $2 \mathrm{~mm}$ were negligible.

The stocks of SOC (Fig. 2) showed a marked spatial variation between replicates, and no significant variations with respect to grazing or temperature treatments. In contrast, all soil profiles at the mesic site held significantly

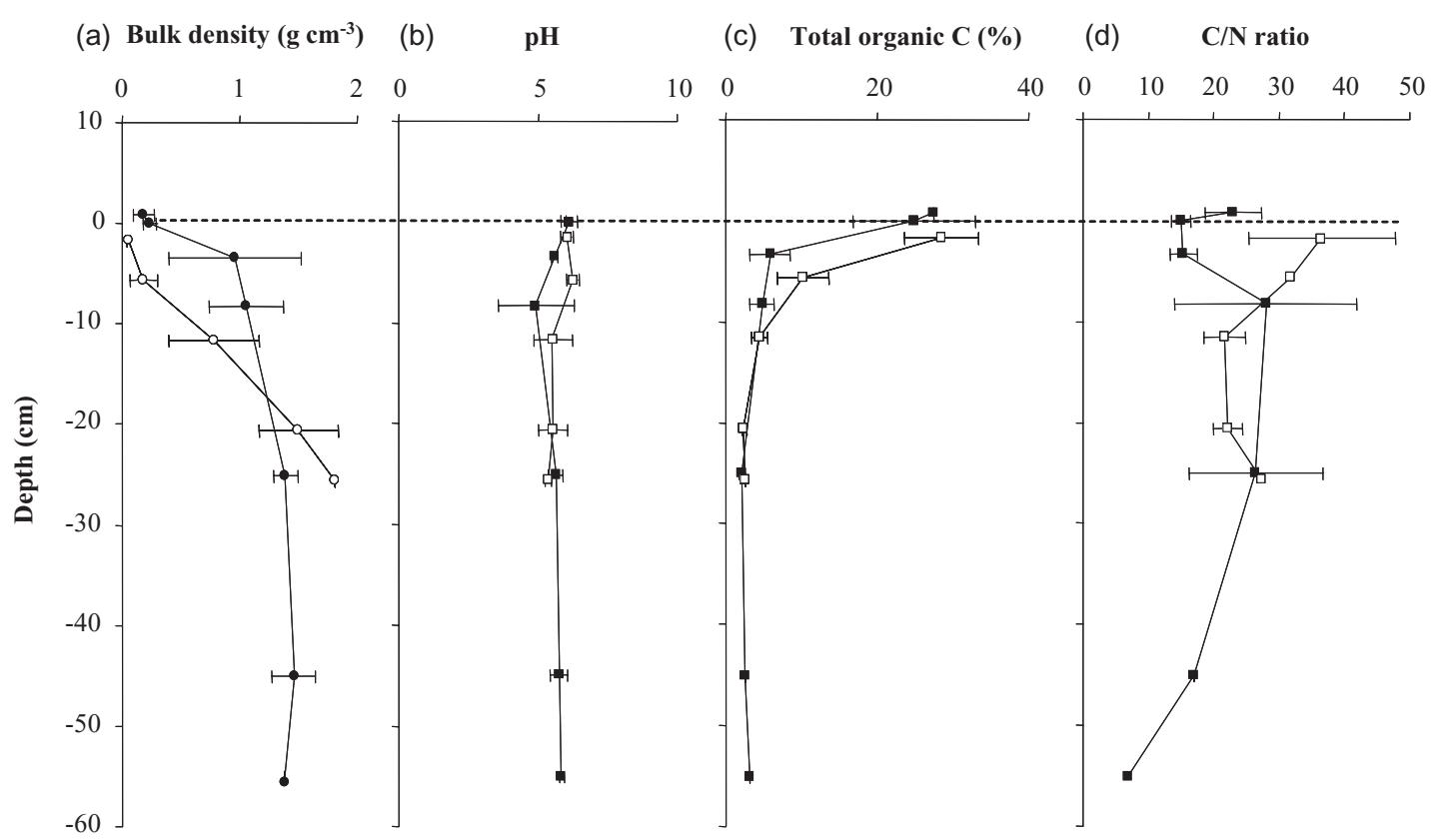

Fig. 1 Geochemical characteristics of two High-Arctic soils in Adventdalen, Spitsbergen, Svalbard: (a) soil bulk density; (b) in situ soil pH; (c) total organic carbon (TOC); (d) C/N ratio (by weight). Open symbols represent the wet site and filled symbols the mesic site. Mean values are shown \pm SD ( $n=3$ ). The horizontal line indicates the soil surface. 

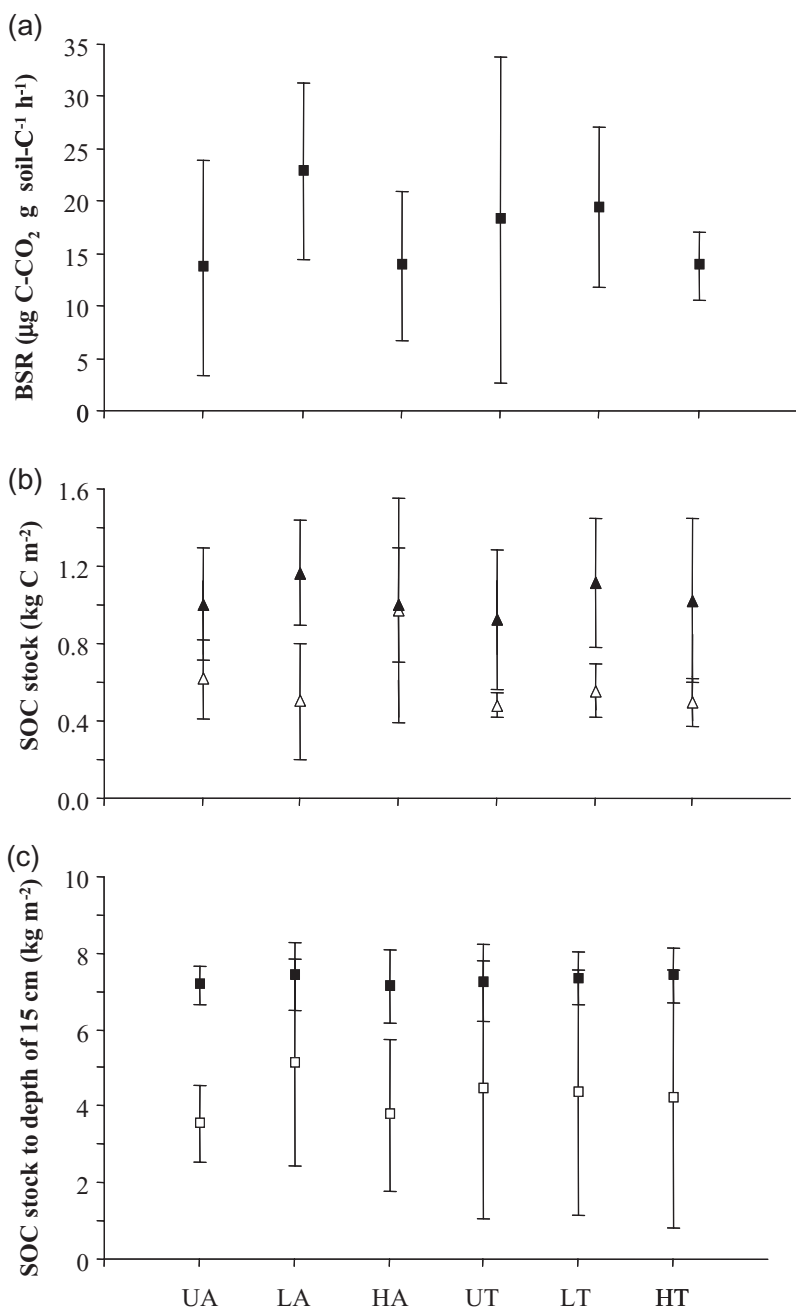

Fig. 2 (a) Basal soil respiration (BSR) of the A horizon at the mesic sites. (b) Soil organic carbon (SOC) stocks in the A horizon at the mesic and wet sites. (c) SOC stocks in the top $15 \mathrm{~cm}$ of soil at mesic and wet site in relation to high $(\mathrm{H})$, low (L) and control (U) grazing intensities, at elevated (T) or ambient (A) temperatures. Open symbols represent the wet site and filled symbols represent the mesic site. Mean values are shown \pm SD $(n=5)$.

$(P<0.05)$ higher stocks of SOC than the wet site. The fact that the wet soils hold far less SOC than drier sites within the upper $15 \mathrm{~cm}$ is in contradiction to many other regions, but is in line with recent Arctic investigations (Elberling, Nordstrøm et al. 2008; Elberling, Tamstorf et al. 2008). The low SOC content and storage at the wet sites is considered to result from stone layers within the upper $0.5 \mathrm{~m}$ and high sedimentation rates, thereby making a direct comparison between wet and mesic sites questionable. For this reason the following description of data and discussion focuses on treatment effects on the replicate mesic soils.

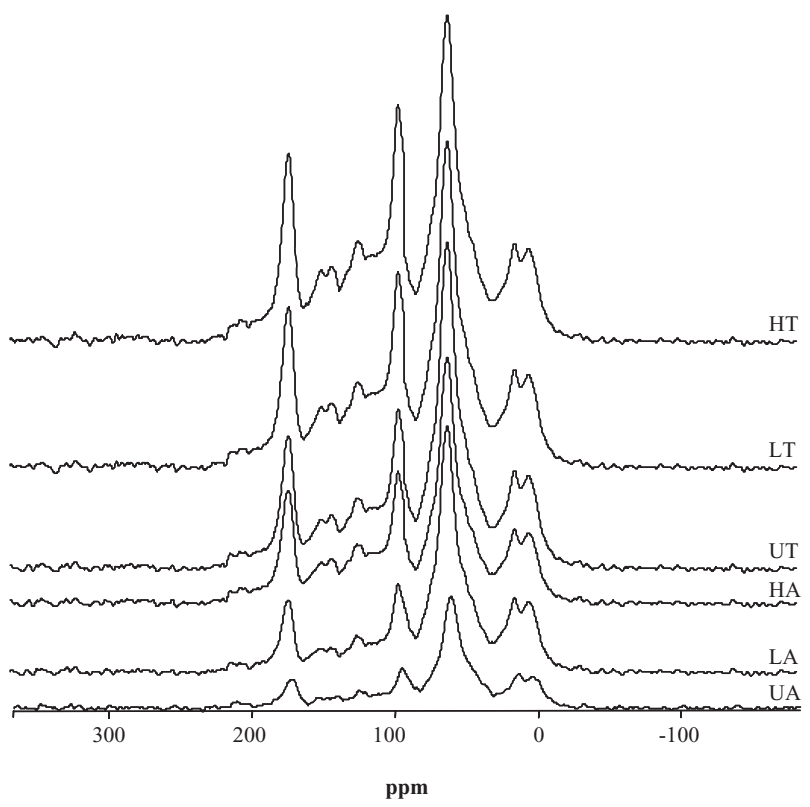

Fig. 3 Solid-state ${ }^{13} \mathrm{C}$ nuclear magnetic resonance spectra of material from the A horizons at mesic sites in relation to high $(\mathrm{H})$, low $(\mathrm{L})$ and control (U) grazing intensities, at elevated (T) or ambient (A) temperatures.

\section{Basal soil respiration}

Basal soil respiration (BSR) was measured for the A horizons at the mesic site at a temperature about $5^{\circ} \mathrm{C}$ (Fig. 2). The $\mathrm{CO}_{2}$ production rates (microbial respiration) were between $13.6 \pm 10.3$ and $22.9 \pm 8.5 \mu \mathrm{g} \mathrm{CO}_{2} \mathrm{~g}_{\text {soil }} \mathrm{C}^{-1} \mathrm{~h}^{-1}$ $( \pm \mathrm{SD})$. The range of $\mathrm{CO}_{2}$ production is comparable with previously reported $\mathrm{CO}_{2}$ production rates for similar soil, of about $10-30 \mu \mathrm{g} \mathrm{CO}_{2} \mathrm{~g}$ soil- $\mathrm{C}^{-1} \mathrm{~h}^{-1}$ (Elberling et al. 2004). There is no clear trend resulting from warming or the different grazing intensities, with relatively large variations between 24 and $85 \%$ (SD) within each treatment (five replicates). However, low grazing intensity seems to favour a higher $\mathrm{CO}_{2}$ release per unit carbon compared with ungrazed and highly grazed sites. This is a direct measure of turnover, and signals a faster, but not significant, turnover in the case of low grazing.

\section{Composition of SOM}

${ }^{13} \mathrm{C}$ solid-state NMR spectroscopy was used to characterize the organic matter composition of the samples (soil fraction $<2 \mathrm{~mm}$ ) from the A horizon at the mesic site. The NMR spectra show comparable signals and intensity distributions between different treatments within the one single block selected for NMR analysis (Fig. 3). This block was the one with the largest treatment differences at the mesic site. The intensity distribution (in \%) for the treatments characterizes the relative concentrations of the 
Table 1 Intensity distribution in the solid-state cross-polarization magic-angle spinning ${ }^{13} \mathrm{C}$ spectra of one mesic block. Treatments were as follows: ungrazed, at ambient temperature (UA); low grazing, i.e., two geese grazing for $1 \mathrm{~h}$, at ambient temperature (LA); high grazing, i.e., two geese grazing for $5 \mathrm{~h}$, at ambient temperature (HA); ungrazed with open-topped chamber (OTC) (UT); low grazing with OTC (LT); and high grazing with OTC (HT).

\begin{tabular}{|c|c|c|c|c|c|c|c|c|}
\hline \multirow[b]{3}{*}{ Treatment } & \multicolumn{2}{|c|}{ Carboxyl C } & \multicolumn{2}{|c|}{ Aromatic C } & \multicolumn{3}{|c|}{ O-N-alkyl C } & \multirow[t]{2}{*}{ Alkyl C } \\
\hline & \multicolumn{7}{|c|}{ Chemical shift region (ppm) } & \\
\hline & $220-180$ & $180-160$ & $160-140$ & $140-110$ & 110-90 & $90-60$ & $60-45$ & $45-10$ \\
\hline UA & 2.715 & 7.742 & 3.955 & 8.978 & 10.675 & 39.146 & 8.130 & 18.638 \\
\hline LA & 2.722 & 8.660 & 4.042 & 8.902 & 10.583 & 37.936 & 7.903 & 19.220 \\
\hline HA & 2.867 & 8.640 & 5.365 & 11.182 & 9.840 & 33.666 & 7.810 & 20.599 \\
\hline UT & 1.541 & 6.767 & 3.902 & 8.876 & 11.045 & 40.043 & 8.724 & 19.077 \\
\hline LT & 1.750 & 7.053 & 4.235 & 9.398 & 10.601 & 39.043 & 8.762 & 19.145 \\
\hline HT & 1.171 & 6.790 & 3.820 & 9.129 & 12.022 & 42.663 & 7.601 & 16.796 \\
\hline
\end{tabular}

carbon fractions (Table 1) in regard to eight standard integrated chemical shift regions that represent different groups in terms of the chemical structure of the SOC. The spectra are dominated (about $40 \%$ ) by an intense O-alkyl carbon signal (45-90 ppm), which is typically assigned to carbohydrates, celluloses, hemicelluloses and the aliphatic parts of lignin structures. About $20 \%$ is assigned to methyl-C groups in long-chain aliphatic carbon, such as fatty acids, waxes, cutins, suberins or lipids, and in shortchain structures such as acetate or amino acids (45$10 \mathrm{ppm})$. Two weak aromatic carbon peaks were noted: one assigned to unsubstituted and alkyl-substituted aromatic carbon (110-140 ppm) and one assigned to phenolic carbon (150-160 ppm). A low contribution of carbonyl carbon (180-220 ppm) of only $1-3 \%$ was revealed, which can be attributed to ketone and aldehyde carbon. The high relative intensity in the carboxyl/ amide-C region (180-165 ppm) of 7-9\% indicates a high oxidization state of organic material, and supports the assignment of the region 45-0 ppm to mainly short-chain alkyl acids. The spectra are similar to those from other investigations of Arctic tundra soils (Dai et al. 2002). The most marked trend in relation to treatments is the increasing carboxyl carbon peak at around 175 ppm, but the effect is small and close to the precision of the measurements. Thus, neither grazing nor moderate temperature increase seem to significantly influence the composition of near-surface SOC characteristics.

\section{Seasonal trends in temperature, snow and moisture content}

Trends in air temperature during the 2007/08 field season and for the last 10 years (Fig. 4) indicate that the study year was a fairly typical year, and that periods of thawing during winter occurred. Soil temperature at the mesic site was about $8^{\circ} \mathrm{C}$ in July and dropped to $-7^{\circ} \mathrm{C}$ in November, and at the wet site dropped from $6^{\circ} \mathrm{C}$ to $-0.5^{\circ} \mathrm{C}$ in the same period. Soil temperature during winter did not drop below $-2.5^{\circ} \mathrm{C}$ at the wet site, in contrast to the mesic site where temperatures reached $-23^{\circ} \mathrm{C}$ in March. The mean annual soil temperature was $-4.8^{\circ} \mathrm{C}$ at the mesic site and $0.3^{\circ} \mathrm{C}$ at the wet site. OTCs increased the near-surface temperatures $(2 \mathrm{~cm})$ in the growing season by $1^{\circ} \mathrm{C}$ at the mesic site, but no measurable increase was observed at the wet site, which is similar to findings in previous years (Cooper et al. 2006; Sjögersten et al. 2008).

A thin snow cover appeared after 2 October 2007 $(<5 \mathrm{~cm})$. After precipitation on 17 October 2007, the snow cover increased to $50 \mathrm{~cm}$ (wet site) and $0-10 \mathrm{~cm}$ (mesic site). In the mesic site, snow depth increased again after 15 December to values between 30 and $50 \mathrm{~cm}$, but remained less than $20 \mathrm{~cm}$ for most of the winter. The soil moisture (by volume) varied more within the mesic site than within the wet site (Fig. 4). At the mesic site, the soil moisture was about $30 \%(n=4)$, and deceased to $15 \%$ in October, whereas at the wet site it was close to $100 \%$ $(n=4)$ until the water started freezing, and then dropped down to about $50 \%$ in October. Soil temperatures at $2 \mathrm{~cm}$ depth, water content and snow distribution illustrate that wet soils with snow remain markedly warmer throughout the winter, in contrast to drier soils with less snow.

\section{Observed and simulated soil respiration}

Observed soil $\mathrm{CO}_{2}$ effluxes vary similarly at both mesic and wet sites, which is in line with previously reported seasonal values at nearby locations (Elberling 2007). Observed $\mathrm{CO}_{2}$ effluxes $(n=30$ for each soil type) decreased from $1.7 \mu \mathrm{mol} \mathrm{CO}_{2} \mathrm{~m}^{-2} \mathrm{~s}^{-1}$ during mid summer (July) to $0.3 \mu \mathrm{mol} \mathrm{CO}_{2} \mathrm{~m}^{-2} \mathrm{~s}^{-1}$ in November at the mesic site, and from 1.3 to $0.6 \mu \mathrm{mol} \mathrm{CO}_{2} \mathrm{~m}^{-2} \mathrm{~s}^{-1}$ at the wet site (Fig. 4). The growing season effluxes are comparable with the previously reported $\mathrm{CO}_{2}$ efflux for July (Oberbauer 

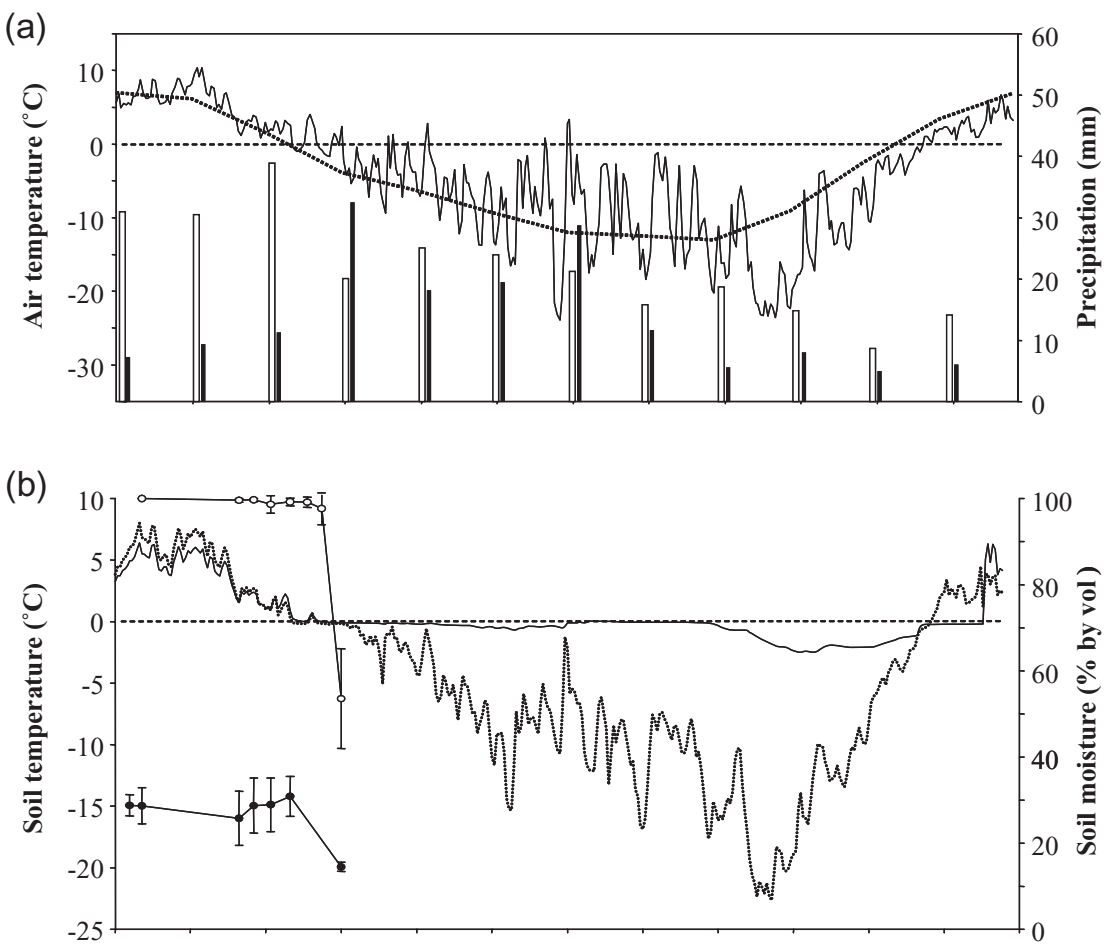

Fig. 4 Seasonal variations observed for wet and mesic soils in Adventdalen. (a) Air temperatures during 2007/08 and 1997-2007 are shown with solid and dashed lines, respectively, and precipitation during 2007/08 and 1997-2007 are shown with black and grey bars, respectively. (b) The soil temperatures $(2 \mathrm{~cm})$ during 2007/08 for mesic and wet sites are shown with dashed and solid lines, whereas water content measurements at wet and mesic sites are shown with open and filled circles, respectively. (c) Observed and simulated soil $\mathrm{CO}_{2}$ effluxes for mesic (solid squares and dashed line) and wet sites (open squares and solid line). Standard deviations of effluxes are shown as bars $(n=30)$. Lines are the simulated soil respiration based on soil temperatures observed at a depth of $2 \mathrm{~cm}$.

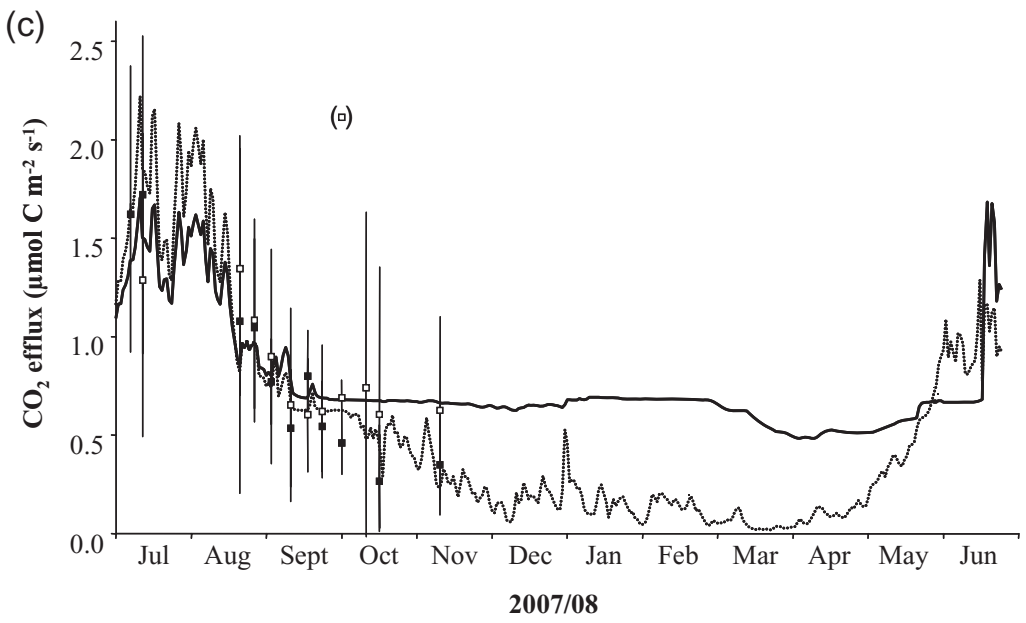

et al. 1992; Elberling et al. 2004). Measurements of $\mathrm{CO}_{2}$ effluxes (Figs. 4, 5) indicate temporal trends driven mainly by near-surface temperatures, but no significant effects of grazing were found. One standard deviation within each treatment for a specific soil type was on average $25 \%$ of the mean effluxes measured. Observed effluxes were significantly higher at the mesic site from July until the end of August compared with those at the wet site.

The soil $\mathrm{CO}_{2}$ efflux in mesic controls were slightly less temperature sensitive than those in the wet site. Mesic controls had an increase in reaction rate per $10^{\circ} \mathrm{C}\left(Q_{10}\right)$ of 3.3 compared with 4.1 at the wet site. The highest $Q_{10}$ values were calculated for warmed mesic plots (Fig. 5). Previously reported $Q_{10}$ values ranged from 1.2 to 3.4 (Elberling et al. 2004; Sommerkorn 2008) and from 5.0 to 7.1 at nearby sites in Svalbard (Elberling 2007). Soil moisture was tested, but no relationship of the fieldobserved soil moisture content $(n=30)$ and soil $\mathrm{CO}_{2}$ effluxes was found.

Based on observed soil temperatures (Fig. 4) and soil type and treatment-specific $Q_{10}$ values (Fig. 5), soil $\mathrm{CO}_{2}$ effluxes were simulated for one year (Fig. 4). This simple model, which neglects other environmental drivers such as water and oxygen, suggests that fluctuations continued during the cold season at the mesic site, with minimum 


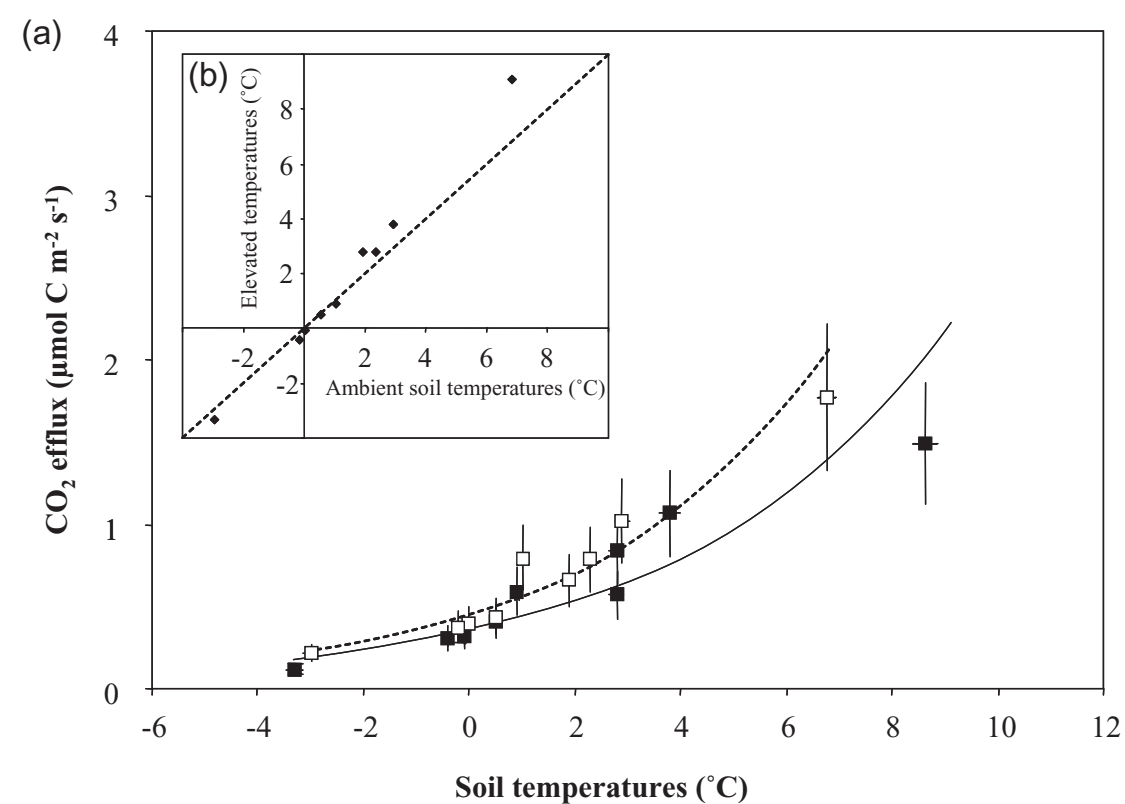

Fig. 5 (a) Observed soil $\mathrm{CO}_{2}$ effluxes for nongrazed mesic sites with and without opentopped chamber (OTC) warming as a function of soil temperatures. Standard deviations of effluxes are shown as bars. Lines are regression equations used for calculating $Q_{10}$ values, and are used to simulate seasonal trends in soil respiration (Fig. 4 based on soil temperatures observed at a depth of $2 \mathrm{~cm}$ ). Fluxes measured at ambient temperatures are shown with filled symbols $\left(Q_{10}=3.3 ; R^{2}=0.93\right)$, whereas measurements at OTCS/warmer temperatures are shown with open symbols $\left(Q_{10}=8.7\right.$; $R^{2}=0.87$ ). (b) Warming versus ambient temperatures measured at non-grazed mesic sites (the $1: 1$ line is indicated by the dashed line). predicted values about $0.02 \mu \mathrm{mol} \mathrm{CO}_{2} \mathrm{~m}^{-2} \mathrm{~s}^{-1}$ in April. In contrast, effluxes were relatively stable at the wet site, ranging from 0.5 to $0.6 \mu \mathrm{mol} \mathrm{CO}_{2} \mathrm{~m}^{-2} \mathrm{~s}^{-1}$. However, the decreasing efflux in early winter was disrupted, with a large observed $\mathrm{CO}_{2}$ efflux of $1.3 \mu \mathrm{mol} \mathrm{CO}_{2} \mathrm{~m}^{-2} \mathrm{~s}^{-1}$ in the beginning of October at the wet site. This event (shown in Fig. $4 \mathrm{c}$ as a data point in parentheses) appears to be linked to physical freeze-thaw events that lead to bursts of $\mathrm{CO}_{2}$, similar to those reported by Elberling \& Brandt (2003) during soil thawing and Mastepanov et al. (2008) for late-season methane emissions from tundra regions. This event has not been included further in the data interpretation and modelling.

The soil $\mathrm{CO}_{2}$ efflux (both observed and modelled) was higher at the wet site than at the mesic site during the cold season, until the beginning of June. Thereafter, modelled $\mathrm{CO}_{2}$ effluxes at the mesic site exceeded the effluxes at the wet site, until the end of June, when the effluxes from the wet site increased significantly. Our models predicted higher $\mathrm{CO}_{2}$ effluxes during spring at the mesic site, as observed earlier in the FRAGILE project (Sjögersten et al. 2008).

The estimated annual soil $\mathrm{CO}_{2}$ efflux was $292 \mathrm{~g} \mathrm{C} \mathrm{m}^{-2}$ at the wet site and only $204 \mathrm{~g} \mathrm{C} \mathrm{m}^{-2}$ at the mesic site. These annual fluxes are higher than previously reported rates from Svalbard. Elberling (2007) reported total annual soil $\mathrm{CO}_{2}$ effluxes ranging from $103 \mathrm{~g} \mathrm{C} \mathrm{m}^{-2}$ in soils under Cassiope to $176 \mathrm{~g} \mathrm{C} \mathrm{m}^{-2}$ in soils under Salix, and Morgner et al. (2010 [this issue]) reported from a nearby mesic meadow $\left(162 \mathrm{~g} \mathrm{C} \mathrm{m}^{-2}\right)$ and a Cassiope heath $\left(125 \mathrm{~g} \mathrm{C} \mathrm{m}^{-2}\right)$ in Adventdalen. In both cases the same methodology was used, underlying the value of investi- gating several vegetation/soil types in an area. We separated the year into winter and summer using the date of the start of continuously negative (winter) or positive (summer) soil temperatures. Winter respiration $(22$ September-29 May) was about 30\% of the annual $\mathrm{CO}_{2}$ efflux at the mesic site, and as much as $56 \%$ at the wet site (13 October-21 June). This compares well with the values that Morgner et al. (2010) reported from the nearby mesic meadow (24\%) and heath (33\%), increasing in both vegetation types to $38 \%$ with deeper snow, and with Elberling's (2007) winter estimations of 14\% for Dryas, 20\% for Cassiope and 30\% for Salix. These annual and seasonal $\mathrm{CO}_{2}$ effluxes have important implications on estimates for carbon balance of tundra systems following increasing herbivore activities or increasing temperatures. This study documents clearly that cold-season respiration is a substantial part of the annual respiration, and that values vary markedly between vegetation types. Carbon sink strength is therefore overestimated if cold-season dynamics are not included, and estimates will be less biased at drier sites with little snow accumulation. In this study, the variations in cold-season respiration between vegetation types are mainly the result of differences in spatial and temporal trends in snow distribution.

\section{Treatment-related soil $\mathrm{CO}_{2}$ effluxes and turnover}

We did not find a significant treatment effect, but clear trends emerged. At the mesic site, plots with OTCs had higher soil $\mathrm{CO}_{2}$ effluxes (from $1.5 \pm 0.4$ to $2.5 \pm$ $0.9 \mu \mathrm{mol} \mathrm{CO}_{2} \mathrm{~m}^{-2} \mathrm{yr}^{-1}$ ) than plots with ambient temperature (from $1 \pm 0.3$ to $1.5 \pm 0.8 \mu \mathrm{mol} \mathrm{CO} \mathrm{Cm}^{-2} \mathrm{yr}^{-1}$ ) during 


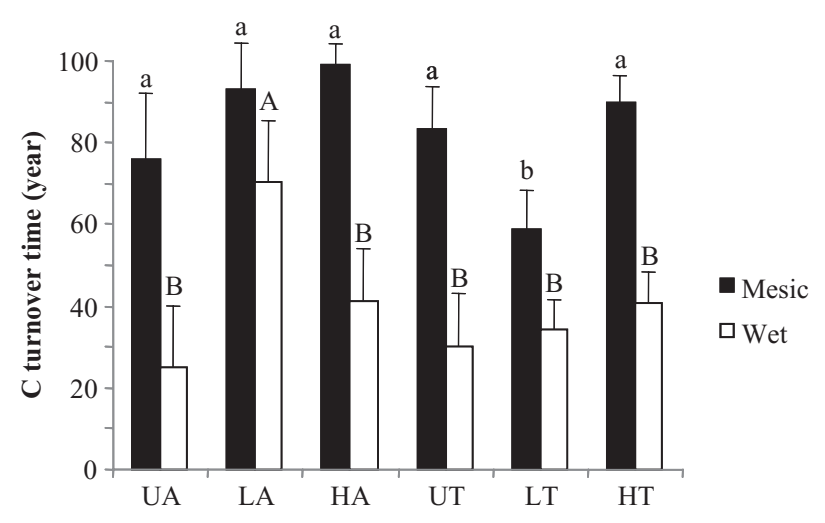

Fig. 6 Calculated turnover for wet and mesic sites for high $(H)$, low $(L)$ and control (U) grazing intensities, at elevated $(T)$ or ambient $(A)$ temperatures. Different letters indicate significant $(P<0.05)$ differences between treatments within each of the two vegetation types.

the growing season. At the wet site, slightly higher $\mathrm{CO}_{2}$ effluxes were measured in ungrazed plots than in grazed plots, with a decreasing effect as winter progressed.

The SOC turnover was calculated as total SOC within the upper $15 \mathrm{~cm}$ divided by the integrated annual $\mathrm{CO}_{2}$ efflux per treatment for the two vegetation and soil types. As root respiration also contributed to the observed effluxes, comparisons between treatments and soil types rely on the fact that the root to microbial respiration ratio is the same, but not necessarily constant, over time. In a review, Hanson et al. (2000) found highly variable contributions of roots to total soil respiration, but in most forest studies the root contribution was in the range of $40-60 \%$. For simplicity, the ratio is assumed to be equal to $50 \%$, although this value may be overestimated, as root respiration probably contributes less, particularly during the winter months (Elberling, Tamstorf et al. 2008). Consequently, the turnover times reported here (Fig. 6) are rough estimates that for each soil sample represent a mean value for different soil carbon pools with markedly different turnover times. Keeping these limitations in mind, significantly faster turnover times are noted for the mesic site for low-grazed (L) treatment, compared with ungrazed (U) and high-grazed $(\mathrm{H})$ treatments. This is in line with conclusions based on basic soil respiration rates. In contrast, a significantly slower turnover time was found for low-grazed treatment in the wet site.

\section{Conclusions and perspectives}

We hypothesized that SOC turnover responds to grazing, that effects of the treatment will decline with time and that the decline will be enhanced as a result of warming.
We found that spatial variability within replicate treatments was large ( $>30 \%$ of mean values) and that soil responses to grazing were not significant. In fact, our results suggest a very complex response, so that some grazing may have an impact, but increasing grazing may have had the opposite effect. The data suggest that impacts are soil-type specific, and that the turnover of SOC may speed up in mesic soils, but slow down in wetter soils, as a result of moderate grazing.

The grazing experiment had very limited impact on SOC stocks and turnover, which can be explained by several factors.

- The experiment ran for only three years, with a lower goose grazing intensity and impact than that experienced in the coastal region of Hudson Bay.

- The expected effect of acceleration of decomposition rates may have aready passed through a maximum and then diminished during the phase of the soil survey. The soil survey was initiated two years after the termination of the FRAGILE experiment, which may have been too late to measure any effects.

- Variations between replicate plots were large, and the variability in water table position and active layer depth considerable. Thus, data were difficult to test statistically as groups. In contrast, the data provide robust estimates on SOC cycling suitable for scaling up.

We conclude that the long-term effects of the grazing experiment were limited, at least in terms of subsurface element cycling, and that any effect of even the high grazing pressure applied in the experiment (up to 3.4 times the "normal" grazing pressure) disappeared within a time period of two years. This is a good indication of the robustness of the tundra to pulses of high grazing activity followed by a recovery period. Finally, this study shows that future work is needed in this area, and should include a study of carbon cycling in the dark and cold season, and could probably benefit from being based on sites near a recent marked naturally increasing goose population where nearby reference sites are available.

\section{Acknowledgements}

This study was funded by: the University Centre in Svalbard, Longyearbyen, Norway; Oticon Fonden; Loeffler; Stennsbys Travel Fond; and the Danish Natural Science Research Council. We thank the staff and students of the University Centre in Svalbard (F.S. Hansen, A. Bailey, J. McAllister, J. Wallenschus and Eike Müller) for help with logistics in the field, and help in the laboratory by G. Lyngsie and S.B. Chouhary (Department of Geography and Geology, University of Copenhagen). We also thank the two reviewers for helpful comments and a thorough editing. 


\section{References}

Abraham K.F., Jefferies R.L. \& Rockwell R.F. 2005. Goose-induced changes in vegetation and land cover between 1976 and 1997 in an Arctic coastal marsh. Arctic, Antarctic, and Alpine Research 37, 269-75.

Billings W.D., Peterson K.M., Shaver G.R. \& Trent A.W. 1977. Root-growth, respiration and carbon-dioxide evolution in an Arctic tundra soil. Arctic and Alpine Research 9, 129-137.

Brady N.C. \& Weil R.R. 2004. The nature and properties of soils. 11 th edn. Upper Saddle River, NJ: Pearson Education.

Cooper E., Jónsdóttir I.S., Chaput D., Küijper D., Loonen M.J.J.E., Pahud A., Sjögersten S., Ubels R., van der Wal R., Woodin S. \& Huiskes A. 2004. Climate change and goose grazing on Svalbard's tundra. Paper presented at the ACIA International Scientific Symposium on Climate Change in the Arctic. 9-12 November, Reykjavik, Iceland.

Cooper E.J., Jónsdóttir I.S. \& Pahud A. 2006. Grazing by captive barnacle geese affects graminoid growth and productivity on Svalbard. Memoirs of the National Institute of Polar Research Special Issue 59, 1-15.

Dai X.Y., Ping C.L. \& Michaelson G.J. 2002. Characterizing soil organic matter in Arctic tundra soils by different analytical approaches. Organic Geochemistry 33, 407-419.

Davidson E.A. \& Janssens I.A. 2006. Temperature sensitivity of soil carbon decomposition and feedbacks to climate change. Nature 440, 165-173.

Elberling B. 2007. Annual soil $\mathrm{CO}_{2}$ effluxes in the High Arctic: the role of snow thickness and vegetation type. Soil Biology $\theta$ Biochemistry 39, 646-654.

Elberling B. \& Brandt K.K. 2003. Uncoupling of microbial $\mathrm{CO}_{2}$ production and release in frozen soil and its implications for field studies of Arctic C cycling. Soil Biology e Biochemistry 35, 263-272.

Elberling B., Jakobsen B.H., Berg P., Søndergaard J. \& Sigsgaard C. 2004. Influence of vegetation, temperature, and water content on soil carbon distribution and mineralization in four High Arctic soils. Arctic, Antarctic, and Alpine Research 36, 528-538.

Elberling B., Nordstrøm C., Grøndahl L., Søgaard H., Friborg T., Christensen T.R., Strøm L., Marchand F. \& Nijs I. 2008. High Arctic soil $\mathrm{CO}_{2}$ and $\mathrm{CH}_{4}$ production controlled by temperature, water, freezing, and snow. Advances in Ecological Research 40, 441-472.

Elberling B., Tamstorf M.P., Michelsen A., Arndal M.F., Sigsgaard C., Illeris L., Bay C., Hansen B.U., Christensen T.R., Hansen E.S., Jakobsen B.H. \& Beyens L. 2008. Soil and plant community-characteristics and dynamics at Zackenberg. Advances in Ecological Research 40, 223-248.

Fahnestock J.T., Jones M.H., Brooks P.D., Walker D.A. \& Welker J.M. 1998. Winter and early spring $\mathrm{CO}_{2}$ efflux from tundra communities of northern Alaska. Journal of Geophysical Research-Atmospheres 103, 29 023-29 027.

Fahnestock J.T., Jones M.H. \& Welker J.M. 1999. Wintertime $\mathrm{CO}_{2}$ efflux from Arctic soils: implications for annual carbon budgets. Global Biogeochemical Cycles 13, 775-779.
Fang C. \& Moncrieff J.B. 2001. The dependence of soil $\mathrm{CO}_{2}$ efflux on temperature. Soil Biology $\theta$ Biochemistry 33, 155-165.

Fox A.D., Madsen J., Boyd H., Kuijken E., Norriss D.W., Tombre I.M. \& Stroud D.A. 2005. Effects of agricultural change on abundance, fitness components and distribution of two Arctic-nesting goose populations. Global Change Biology 11, 881-893.

Gaskin G.J. \& Miller J.D. 1996. Measurement of soil water content using a simplified impedance measuring technique. Journal of Agricultural Research 63, 153-160.

Hanson P.J., Edwards N.T., Garten C.T. \& Andrews J.A. 2000. Separating root and soil microbial contributions to soil respiration: a review of methods and observations. Biogeochemistry 48, 115-146.

Healy R.W., Striegl R.G., Russell T.F., Hutchinson G.L. \& Livingston G.P. 1996. Numerical evaluation of static-chamber measurements of soil-atmosphere gas exchange: identification of physical processes. Soil Science Society of America Journal 60, 740-747.

Jefferies R.L., Jano A.P. \& Abraham K.F. 2006. A biotic agent promotes large-scale catastrophic change in the coastal marshes of Hudson Bay. Journal of Ecology 94, 234-242.

Jónsdóttir I.S. 2005. Terrestrial ecosystems on Svalbard: heterogeneity, complexity and fragility from an Arctic island perspective. Biology and Environment 105B, 155-165.

Knicker H., Gonzalez-Vila F.J., Polvillo O., Gonzalez J.A. \& Almendros G. 2005. Fire-induced transformation of C- and $\mathrm{N}$-forms in different organic soil fractions from a Dystric Cambisol under a Mediterranean pine forest (Pinus pinaster). Soil Biology $\theta$ Biochemistry 37, 701-718.

Knicker H. \& Ludemann H.D. 1995. N-15 and C-13 CPMAS and solution NMR studies of N-15 enriched plant material during 600 days of microbial degradation. Organic Geochemistry 23, 329-341.

Küijper D.P.J., Bakker J.P., Cooper E.J., Ubels R., Jónsdóttir I.S. \& Loonen M.J.J.E. 2006. Intensive grazing by barnacle geese depletes High Arctic seed bank. Canadian Journal of Botany 84, 995-1004.

Lal R., Kimble J.M. \& Stewart B.A. 2000. Advances in soil science. Global climate change and cold regions ecosystems. Washington, DC: Lewis Publishers.

Luo Y. \& Zhou X. 2006. Soil respiration and the environment. London: Elsevier Academic Press.

Mastepanov M., Sigsgaard C., Dlugokencky E.J., Houweling S., Stroem L., Tamstorf M.P. \& Christensen T.R. 2008. Large tundra methane burst during onset of freezing. Nature 456, 628-630.

Morgner E., Elberling B., Strebel D. \& Cooper E.J. 2010. The importance of winter in annual ecosystem respiration in the High Arctic: effects of snow depth in two vegetation types. Polar Research 29, 58-74.

Oberbauer S.F., Gillespie C.T., Cheng W., Gebauer R., Serra A.S. \& Tenhunen J.D. 1992. Environmental effects on $\mathrm{CO}_{2}$ efflux from riparian tundra in the northern foothills of the Brooks Range, Alaska, USA. Oecologia 92, 568-577. 
Sjögersten S.R., van der Wal R. \& Woodin S.J. 2008. Habitat type determines herbivory controls over $\mathrm{CO}_{2}$ fluxes in a warmer Arctic. Ecology 89, 2103-2116.

Sommerkorn M. 2008. Micro-topographic patterns unravel controls of soil water and temperature on soil respiration in three Siberian tundra systems. Soil Biology $\theta$ Biochemistry 40, 1792-1802.

Srivastava D.S. \& Jefferies R.L. 1996. A positive feedback: herbivory, plant growth, salinity, and the desertification of an Arctic salt-marsh. Journal of Ecology 84, 31-42. van der Wal R., Sjögersten S., Woodin S.J., Cooper E.J., Jónsdóttir I.S., Küijper D., Fox T.A.D. \& Huiskes A.D. 2007. Spring feeding by pink-footed geese reduces carbon stocks and sink strength in tundra ecosystems. Global Change Biology 13, 539-545. 